\title{
Therapeutic Potential of the Microbiome in the Treatment of Neuropsychiatric Disorders
}

\author{
Alper Evrensel ${ }^{1,2, * \mathbb{D}}$, Barış Önen Ünsalver ${ }^{3}$ and Mehmet Emin Ceylan ${ }^{4}$ (I) \\ 1 Department of Psychiatry, Uskudar University, PK:34768 Istanbul, Turkey \\ 2 NP Brain Hospital, Saray Mahallesi, Ahmet Tevfik İleri Cad. No: 18, PK:34768 Umraniye Istanbul, Turkey \\ 3 Vocational School of Health Services, Department of Medical Documentation and Secretariat, \\ Uskudar University, PK:34768 Istanbul, Turkey; onenunsalver@gmail.com \\ 4 Departments of Psychology and Philosophy, Uskudar University, PK:34768 Istanbul, Turkey; \\ m.eminceylan@yahoo.com \\ * Correspondence: alperevrensel@gmail.com; Tel.: +90-216-6330633
}

Received: 27 December 2018; Accepted: 29 January 2019; Published: 31 January 2019

check for updates

\begin{abstract}
The search for rational treatment of neuropsychiatric disorders began with the discovery of chlorpromazine in 1951 and continues to evolve. Day by day, new details of the intestinal microbiota-brain axis are coming to light. As the role of microbiota in the etiopathogenesis of neuropsychiatric disorders is more clearly understood, microbiota-based (or as we propose, "fecomodulation") treatment options are increasingly discussed in the context of treatment. Although their history dates back to ancient times, the importance of psychobiotics and fecal microbiota transplantation (FMT) has only recently been recognized. Despite there being few preclinical and clinical studies, the evidence gathered to this point suggests that consideration of the microbiome in the treatment of neuropsychiatric disorders represents an area of significant therapeutic potential. It is increasingly hoped that such treatment options will be more reliable in terms of their side effects, cost, and ease of implementation. However, there remains much to be researched. Questions will be answered through germ-free animal experiments and randomized controlled trials. In this article, the therapeutic potential of microbiota-based options in the treatment of neuropsychiatric disorders is discussed in light of recent research.
\end{abstract}

Keywords: gut microbiota; microbiome; dysbiosis; psychiatry; neurology; fecomodulation; fecal microbiota transplantation; probiotics; prebiotics

\section{Introduction}

Scientific consensus dates the birth of modern psychopharmacology back to 1951 [1]. Similar to the discovery of penicillin, the serendipitous discovery and synthesis of chlorpromazine opened the gates of psychopharmacology and synaptic neurotransmission [2]. The discovery of psychotropics that followed led to further developments in the field [3]. As a consequence of thousands of studies, enormous steps have been taken in terms of the etiopathogenesis and treatment of neuropsychiatric disorders.

Beginning in the 2000s, the focus of psychiatry began to shift from synaptic transmission and monoamine receptor functions to areas such as intestinal microbiota [4], the peripheral system [5], mitochondria [6,7], the mitochondria-microbiota interaction [8], the immune system [9], and neuroinflammation [10].

One of these new areas of interest is the microbiota. Prokaryotes were the first living organisms on earth, and quantitively are the largest group amongst extant species [11]. Humans constitute a "super organism" comprising a combination of eukaryotic and prokaryotic cells [12]. Microorganisms 
have colonized almost every region of the body [13]. These guests communicate with human body cells (just as they do amongst themselves) [14] in a cooperative and commensal manner [15]. It has been suggested that the brain is not sterile and that a "brain microbiota" may also exist [16,17].

The intestinal microbiota is composed of commensal prokaryotes which colonize the intestines (especially the large intestine) [18]. It is estimated that there are approximately 380 trillion microbes in the intestinal microbiota. This is approximately four times the number of adult human cells [19]. The genome of the prokaryote microbiota is large, containing more genes than that of a human [20]. Included in this microbiota are commensal fungi (a mycobiome) [21].

Three-quarters of the microbiota in an adult human is composed of Firmicutes and Bacteroidetes. The ratio of Firmicutes/Bacteroidetes is estimated to be approximately $11 \%$ [22]. Microbiota composition is dynamic and unique and can vary depending on the host's genetic structure, age, nutrition, stress level, medicinal intake, and place of residence (rural or urban) [23-25]. For example, olanzapine (an atypical antipsychotic drug) increases Firmicutes levels and reduces Protobacteria and Actinobacteria levels [26]. Bifidobacteria and Lactobacilli levels decrease in newborns exposed to stress [27,28]. Chronic stress reduces the proportion of Bacteroides and increases the proportion of Clostridium species in the host microbiome [29]. Antibiotics may trigger cytokine imbalances in patients with depression [30]. Use of antibiotics before the age of one correlates with adulthood depression [31]. Long-term broad-spectrum antibiotic use can permanently alter the composition of the intestinal microbiota [32]. Interestingly, minocycline produces antipsychotic-like effects [33].

Elie Metchnikoff's Nobel Prize-winning work in 1908 was related to the role of probiotic microorganisms in the immune system and human health [34]. Shortly after this, the first article to report on the success of Lactobacillus in the treatment of depression ("melancholy" as stated in the article) was published [35]. The idea that there is a correlation between the occurrence of allergies and the use of antibiotics, urban environments, and increased use of cleaning products is known as the "hygiene hypothesis" [36]. Another hypothesis suggests that "old friend" microorganisms have very important functions in human evolution [37,38]. These views have formed the basis of our current understanding of human-microbe interactions.

The study of the intestinal microbiota-brain axis is progressing rapidly today. There is evidence that the intestinal microbiota can act on neuronal function by both direct and indirect means [18]. The immune system seems to play a key role in this bidirectional interaction [39]. It is now thought that both neurons and the brain are affected by many intrinsic and extrinsic factors and that microbiota-induced neuroinflammation has an important role in the etiopathogenesis of neuropsychiatric disorders [40].

Seminal discoveries in the field have led to the realization that the intestinal microbiota-immune system-brain axis must be considered in the treatment of neuropsychiatric disorders. This approach, referred to as "microbiota-based therapy" includes prebiotics, probiotics (psychobiotics), and fecal microbiota transplantation (FMT). In the scientific literature, there are numerous reviews of the mechanisms underlying the gut-brain relationship. However, there are few articles on the therapeutic potential of microbiota in the treatment of neuropsychiatric disorders. In articles related to microbiota-based therapies, psychobiotics are more commonly emphasized. We found very few articles on the potential use of FMT in neuropsychiatric disorders. Therefore, in this article, we propose the term "fecomodulation" and discuss in detail the neuropsychiatric therapeutic potential of these treatments in light of the current literature.

\section{The Microbiome as a New Psychiatric Treatment Option}

The incidence and prevalence of psychiatric diseases have increased in the last three-four decades $[41,42]$. One in every 40 children in the United States is diagnosed with autism spectrum disorder [43]. It has been suggested that this rapid increase may be due to modern dietary habits such as frequent consumption of fast food [44]. Rates of food-related disorders can be reduced through dietary regulation [45]. In addition, the importance of prebiotics and probiotics (psychobiotics) is 
increasingly recognized [39]. In order to understand approaches for which the aim is to manipulate intestinal microbiota to achieve positive therapeutic outcomes, we will first discuss in detail the gut-brain relationship.

\subsection{The Gut-Brain Axis}

Our body is a complex system in which our own cells and commensal microbes coexist symbiotically [40]. Bacteria that live in the intestine and have positive effects on neuronal function are called "psychobiotics" [46]. Psychobiotics play an important role in the immune system, endocrine system, and metabolism by secreting neurohormones, neurotransmitters, and neuropeptides. In this way, they have an important role in the body, especially with regard to brain function [4]. This bidirectional interaction between the intestines and the brain is called the "gut-brain axis" [18].

The digestive tract epithelium has a surface area the size of a tennis court and is the largest mucosal surface in the human body. In normal mucosa, enterocytes are tightly fixed to each other by tight junctions. Enterocytes also secrete mucus. Mucus prevents toxins from directly contacting enterocytes. This effective barrier can be impaired for various reasons (e.g., stress, exogenous glucocorticoids, dysbiosis, and endotoxins) and a "leaky gut" may result. At this stage, bacteria and their toxic metabolites (lipopolysaccharides) can interfere with blood and trigger inflammation [47,48]. Neuroinflammatory parameters increase in autistic mice [49,50]. Psychobiotics reduce the severity of symptoms associated with a leaky gut and neuroinflammation $[48,51,52]$. For example, Bacteroides fragilis can repair bowel leakage and reduce endotoxin-induced autistic behavior [53]. Anti-inflammatory activities of psychobiotics are important in neuropsychiatric disorders (e.g., depression) with low-grade neuroinflammation [4]. However, it is thought that psychobiotics have other beneficial effects as well [54,55].

Microbes can cooperate with the immune system. Prokaryotic cell elements (e.g., cell wall proteins and nucleic acids) activate immune system cells [18]. This contact is established via pattern recognition receptors (PRRs) and toll-like receptors (TLRs) [4]. Commensal bacteria can increase the level of interleukin-10 (IL-10, an anti-inflammatory cytokine) through activation of PRRs [56]. Probiotics such as Lactobacillus GG and Bifidobacterium infantis increase IL-10 levels, reduce proinflammatory cytokine levels, and reduce blood-brain barrier permeability [57]. Psychobiotics inhibit the proinflammatory process by stimulating TLR-2 and TLR-4 [58].

The brain has its own lymphatic drainage system [59]. This lymphatic system forms the basis of the interaction between neurons and the immune system. An increase in proinflammatory cytokines due to pathogenic microbes can alter brain levels of neurotransmitters [60]. They may also provoke proinflammatory processes by inducing prostaglandin synthesis [61]. Psychobiotics can reduce the level of proinflammatory cytokines in systemic circulation and low-level neuroinflammation. However, in a mouse trial, Bifidobacterium longum NCC3001 reduced anxiety levels and normalized low hippocampal brain-derived neurotrophic factor (BDNF) levels without any change in cytokine levels. These findings suggest that probiotics may also act through non-cytokine mechanisms, which could explain the results of the Bifidobacterium longum trial [62]. Brain-derived neurotrophic factor and $\mathrm{N}$-methyl D-aspartate (NMDA) 2a levels in the hippocampus of germ-free (GF) mice are lower than those in mice with a diverse microbiota [63]. Lactobacillus helveticus and Bifidobacterium longum reduced anxiety scores in an animal experiment [54] and the same bacteria had similar effects on healthy human volunteers [64].

Another means of contact between the microbiota and nervous system is the myenteric plexus. Myenteric neurons are in the submucosa and establish direct contact with microorganisms in the lumen [65]. Bifidobacterium longum shows its anxiolytic effect by impacting myenteric neurons [66]. Lactobacillus reuteri reduces neuronal hyperexcitation [67]. Probiotics change peristaltism by affecting ion transport [68]. Microbiota bacteria are also effective in modifying the function of glia cells in addition to neurons [69]. In addition to these effects on bacteria, GF conditions also have unique effects 
on neuron functioning. Several abnormalities have been detected in the enteric nervous system of GF mice [70] and the neuronal excitability levels of such mice are low [71].

One of the most important means of communication within the gut-brain axis is the vagus nerve. The vagus nerve regulates parasympathetic activity between the brain and gastrointestinal tract and has effects on immune system function [72]. Stress, nutrition, and exercise affect vagal nerve tone [73-75]. Stimulation of the vagus nerve produces analgesic [76], anti-inflammatory [72], antidepressant-anxiolytic [77], and antiepileptic [78] effects. Antidepressant and anxiolytic drugs also affect vagal tone [79]. While some studies reported psychobiotic activity after vagotomy $[66,80]$, no such activity was reported in another study [81]. However, it appears that the vagus nerve has an important function in psychobiotic activity.

Dietary-derived plant fiber is digested with enzymes synthesized by the microbiota [82]. Short-chain fatty acids (SCFAs) are produced from fiber in the intestinal lumen [83]. Short-chain fatty acids (acetate, butyrate, propionate, and lactate) may cross the blood-brain barrier, but their effect on synaptic transmission is still unclear [84]. By affecting free fatty acid receptors [85] and through epigenetic mechanisms [86], SCFAs can alter neuromodulation [87].

Bacteria of the microbiota have metabolic functions other than SCFA production. These metabolites have an important role in the development of neuroinflammation [88]. Plasma tryptophan levels of GF mice are higher than in normal (i.e., with microbiota) mice. The plasma serotonin levels of normal mice are approximately three-fold higher than in GF mice [89]. Brain-derived neurotrophic factor levels, 5-hydroxitriptamine (serotonin) receptor 1A (5HT1A) expression [80], and anxiety scores are low in GF mice [90]. Bacteria of the microbiota may also have an effect on the metabolism of enterochromaffin cells.

Intestinal bacteria synthesize neurotransmitters. Escherichia produce noradrenaline and serotonin, Enterococcus and Streptococcus produce serotonin, Bacillus produce dopamine and noradrenaline, and Bifidobacteria and Lactobacillus produce $\gamma$-aminobutyric acid (GABA) [91]. These neurotransmitters may affect the activity of the enteric nervous system. The microbiota also have effects on brain function by producing neuroactive substances (e.g., synaptophysin, BDNF, post-synaptic density-95) [92]. Studies on this subject are shown in Table 1.

\subsection{Therapeutic Potential of Psychobiotics}

Unexpected results from animal experiments have revealed that the microbiome may have potential in the treatment of neuropsychiatric disorders. In this respect, probably the first article on the efficacy of Lactobacilli in the treatment of depression was published in 1910 [35]. In recent years (and because of increasing interest in the subject) many animal trials have been performed. A study on the psychobiotic activity of Bifidobacterium infantis reported that although there was no significant difference between the test protocols of the experimental and control groups, there was evidence of antidepressant-like activity in blood tests [93]. There was no significant difference between two groups in a study in which the antidepressant activity of Bifidobacterium infantis was compared with citalopram (an antidepressant) [94]. Bifidobacterium pseudocatenulatum CECT 7765 showed anxiolytic activity by reducing the acute stress response in mice. Additionally, inflammatory markers decreased and dysbiosis regressed [95]. Lactobacillus rhamnosus JB-1 has an anxiolytic effect by modulating GABA (an inhibitory neurotransmitter) function [96]. In contrast to these findings, the same bacterium was found to increase the level of glutamate (an excitatory neurotransmitter) [97]. Anxiolytic activity of another Lactobacillus strain (Lactobacillus helveticus) was compared with citalopram and found to be similar [98]. In another recent study on the psychobiotic efficacy of Lactobacilli, the antidepressant and anxiolytic activity of Lactobacillus rhamnosus JB-1 was compared with fluoxetine (an antidepressant). Psychobiotic activity was observed in BALB/c mice, but not observed in Swiss Webster mice [99].

There are few human studies on the effectiveness of psychobiotics in various neuropsychiatric conditions. In a study comparing Lactobacillus salivarius and Bifidobacterium infantis in subjects with irritable bowel syndrome ( 48 females, 27 males), the positive effects observed with Bifidobacterium were 
not found in the group receiving Lactobacillus [57]. Two years later, in a trial using Lactobacillus casei Shirota, a partial positive effect on mood and negative effects on cognitive function were found [100]. In two randomized control trials published in 2011, the efficacy of Lactobacillus helveticus R0052 and Bifidobacterium longum on neuropsychiatric parameters was evaluated. While depression and anxiety scores regressed, no significant change was found in tests that measured cognitive function $[54,64]$. In another study, Bifidobacterium longum 1714 use increased cognitive performance [101]. In a more recent study, high Bacteroides levels and low Lachnospiraceae levels were found in the stool of patients diagnosed with depression [102].

In a study assessing the effectiveness of psychobiotics on performance anxiety, Lactobacillus casei strain Shirota that was used for eight weeks decreased plasma cortisol levels before an exam [103], while in the other, Lactobacillus gasseri reduced the fatigue level of athletes after a competition [104]. Positive results were obtained in two studies that analyzed the psychobiotic activity of Lactobacillus and Bifidobacteria with functional magnetic resonance imaging fMRI $[105,106]$. In spite of these positive results, negative results have been reported in some studies [100,107]. These conflicting results may arise from methodological differences. Therefore, randomized controlled studies with large samples are needed.

Bacteria are living entities that require nutrients to live. Our food is the source of their nutrients. Nutrients of probiotic bacteria are called "prebiotics" [18]. For example, Bacteroides fragilis and Faecalibacterium prausnitzii synthesize SCFAs by digesting fiber $[108,109]$. Therefore, fiber has the characteristics of a prebiotic.

Psychotropic drugs used in the treatment of neuropsychiatric disorders may alter the composition of the microbiota. Most psychotropic drugs show antibiotic activity [25]. The first antidepressant molecule was iproniazid (a monoamine oxidase (MAO) inhibitor), an anti-tuberculosis drug [110]. The positive effects of psychobiotics can be negated when they are administered to patients receiving psychotropic agents. The potent antipsychotic chlorpromazine has antibiotic/antifungal activity [111]. Monoamine oxidase inhibitors produce an antimicrobial effect by inhibiting cell wall synthesis, selective serotonin reuptake inhibitors (SSRIs) by inhibiting the efflux pump, and tricyclic antidepressants show an antimicrobial effect by inhibiting DNA gyrase (an antiplasmid effect) [25]. In addition to their synaptic effects, currently prescribed psychotropics may also contribute to a therapeutic effect by altering the composition of the microbiota [4].

\subsection{Therapeutic Potential of Fecal Microbiota Transplantation}

The fecal microbiota transplantation is a treatment method that dramatically alters the composition of the intestinal microbiota and correct dysbiosis [112]. In order to recognize the potency of FMT in the treatment of neuropsychiatric disorders, it is useful to look at the research in which fecal microbiota analysis has been performed.

In a study [113], the composition of bacteria in the stool of patients with depression $(n=46)$ and healthy individuals $(n=30)$ was compared. Firmicutes levels were found to be lower in the stool of patients with depression, while the levels of Bacterioides, Proteobacteria, and Actinobacteria were found to be higher in the group with depression [113]. The authors interpreted this finding as being the consequence of patients with depression having a decreased proportion of beneficial bacteria as compared to harmful bacteria. First-episode psychosis cases $(n=28)$ and healthy individuals $(n=16)$ were compared in a more recent study in which the fecal microbiota composition was determined using quantitative real-time PCR and metagenomic analyses [114]. The stool of the participants were analyzed at the beginning and at the 2nd and 12th months. Fecal Lactobacillus levels of first-episode psychosis patients increased with treatment and this increase was correlated with symptom severity and treatment response. Even though the results of these studies are significant, further research is needed if stool microbiota analysis is to be used as a biomarker and to establish a cause-effect relationship. 
An experiment by Zheng et al. is considered seminal in this field. In their GF mouse experiment, mice transplanted with a "depression microbiota" taken from patients with depression were found to have a pattern of behavior consistent with depression, as compared to mice transplanted with a "healthy microbiota" taken from healthy individuals [115]. Kelly and colleagues achieved similar results in another study of similar design entitled "Transferring the Blues" [116].

There are case reports that FMT reduces the symptoms of autism in children [117]. In a study performed on a small sample $(n=18)$, children with autism underwent FMT (microbiota transfer therapy) following antibiotic (vancomycin) therapy for two weeks to modify intestinal microbiota [118]. The behavioral and gastrointestinal symptoms of autism decreased, and this condition lasted for 8 weeks. Fecal microbiota transplantation that is done once might not be sufficient to restore the microbiota composition sufficiently. Residual pathogenic bacteria (pathobionts) might be proliferating in time, resulting in the formation of old microbiota composition. Repetitive FMT may be needed to keep the restored and healthy microbiota. However, experimental and clinical studies are needed to further clarify these issues.

The main indications for FMT are Clostridium difficile infection (CDI) and inflammatory bowel disease (ulcerative colitis and Crohn's disease). Fecal microbiota transplantation is considered to be a reliable treatment method for these conditions, as the health of the microbiota in the stool of these patients is quite poor. In a follow-up study, serious side effects were not reported [119]. Patients may experience abdominal pain, gas, diarrhea, and constipation on the day of FMT application [120]. In a study with a large sample $(n=317)$, complications (bleeding, peritonitis, and enteritis) were reported only in three cases [121]. In another study, colitis was exacerbated [122]. Serious complications such as death due to peritonitis can also be seen following FMT that was done for conditions other than neuropsychiatric disorders [123]. The risks of FMT in psychiatric indications are not yet known. Randomized controlled trials are needed to clarify these risks.

Table 1. Summary of important preclinical and clinical studies on the gut-microbiota-brain axis.

\begin{tabular}{|c|c|c|c|}
\hline Target Sample & Evaluation Tools & $\begin{array}{l}\text { Outcomes and Mechanism of } \\
\text { Disease Modulation }\end{array}$ & Research \\
\hline 11 healthy subjects & Fecal sample analysis via $16 \mathrm{~S}$ rRNA & $\begin{array}{l}\text { Microbiota composition may change } \\
\text { based on diet. }\end{array}$ & David et al. [23] \\
\hline Wistar rats & $\begin{array}{c}\text { Feeding patterns, food preference, } \\
\text { locomotor activity, and body } \\
\text { temperature }\end{array}$ & $\begin{array}{c}\text { Olanzapine leads to increases in the } \\
\text { levels of Firmicutes and decreases in } \\
\text { the levels of Protobacteria and } \\
\text { Actinobacteria. }\end{array}$ & Davey et al. [26] \\
\hline $\begin{array}{l}\text { Male Sprague Dawley } \\
\text { rat pups }\end{array}$ & $\begin{array}{c}\text { Endocrine and immune } \\
\text { measurements, polymerase chain } \\
\text { reaction of partial 16S ribosomal RNA } \\
\text { gene fragments and analysis by } \\
\text { denaturing gradient gel } \\
\text { electrophoresis }\end{array}$ & $\begin{array}{c}\text { The stress caused by separation } \\
\text { from the mother reduces the levels } \\
\text { of Bifidobacteria and Lactobacilli in } \\
\text { newborn rat guts. }\end{array}$ & O'Mahony et al. [28] \\
\hline Male CD-1 mice & $\begin{array}{l}\text { Social disruption tests, real-time PCR, } \\
\text { bacterial tag-encoded FLX amplicon } \\
\text { pyrosequencing }\end{array}$ & $\begin{array}{l}\text { Bacteroides species decrease and } \\
\text { Clostridium species increase in the } \\
\text { feces of mice that are exposed to } \\
\text { chronic stress. }\end{array}$ & Bailey et al. [29] \\
\hline $\begin{array}{l}\text { Adult male } \\
\text { Sprague-Dawley rats }\end{array}$ & $\begin{array}{l}\text { Porsolt's test, levels of components of } \\
\text { the toll-like receptor } 4 \text { (TLR- } 4 \text { ) } \\
\text { signaling pathway, of } \\
\text { lipopolysaccharide (LPS), and of } \\
\text { different inflammatory, } \\
\text { oxidative/nitrosative, and } \\
\text { anti-inflammatory mediators were } \\
\text { measured by RT-PCR, Western blot } \\
\text { and/or ELISA in brain prefrontal } \\
\text { cortex. }\end{array}$ & $\begin{array}{l}\text { Plasma LPS, LPS-binding protein, } \\
\text { brain LPS receptor and TLR4 levels } \\
\text { were found to be high. }\end{array}$ & Garate et al. [30] \\
\hline $\begin{array}{l}871 \text { European mothers } \\
\text { and their children }\end{array}$ & $\begin{array}{l}\text { Maternal interview, The Strengths and } \\
\text { Difficulties Questionnaire, Conners } \\
\text { Rating Scales Revised, The Centre for } \\
\text { Epidemiological Studies Depression } \\
\text { Scale for Children, intelligence tests }\end{array}$ & $\begin{array}{l}\text { Correlation between usage of } \\
\text { antibiotics before the age of one year } \\
\text { and adulthood depression. }\end{array}$ & Slykerman et al. [31] \\
\hline
\end{tabular}


Table 1. Cont.

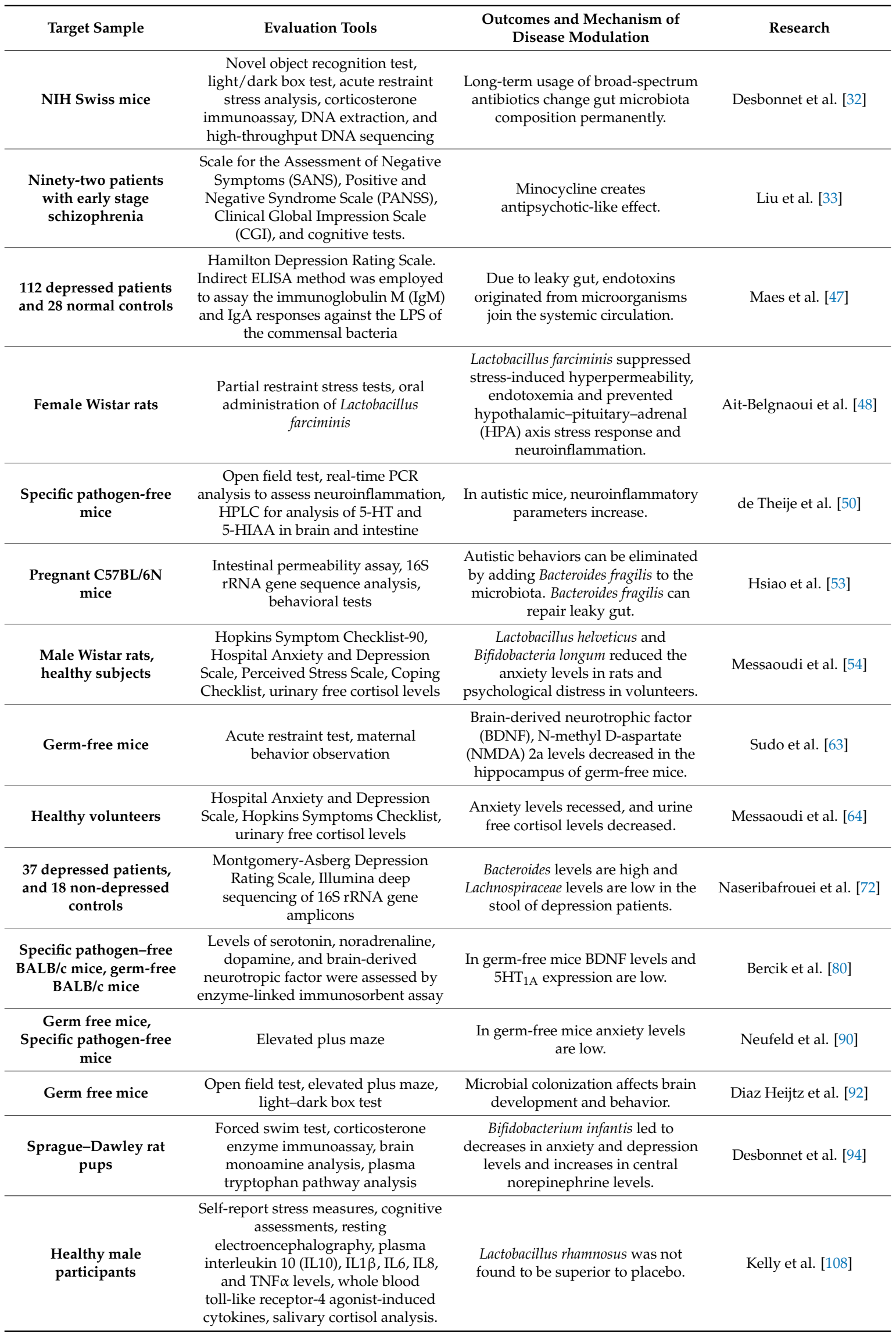


Table 1. Cont.

\begin{tabular}{|c|c|c|c|}
\hline Target Sample & Evaluation Tools & $\begin{array}{l}\text { Outcomes and Mechanism of } \\
\text { Disease Modulation }\end{array}$ & Research \\
\hline $\begin{array}{c}\text { Patients with major } \\
\text { depression and healthy } \\
\text { subjects }\end{array}$ & $\begin{array}{c}\text { Hamilton's Depression Scale, } \\
\text { Montgomery-Asberg Depression } \\
\text { Rating Scale, Serum tumor necrosis } \\
\text { factor-a, IL-1b, IL-6, brain-derived } \\
\text { neurotrophic factor analysis, } \\
\text { polymerase chain reaction and } \\
\text { pyrosequencing }\end{array}$ & $\begin{array}{l}\text { Increases in the levels of Alistipes, } \\
\text { Enterobacteriaceae Bacteroides, } \\
\text { Proteobacteria and Actinobacteria and } \\
\text { decreases in the levels of } \\
\text { Faecalibacterium and Firmicutes in the } \\
\text { fecal samples of depression patients. }\end{array}$ & Jiang et al. [114] \\
\hline $\begin{array}{c}\text { Male germ-free } \\
\text { Kunming mice and } \\
\text { Specific pathogen-free } \\
\text { Kunming mice }\end{array}$ & $\begin{array}{l}\text { Open-field test, Y-maze, tail } \\
\text { suspension test, forced swimming test }\end{array}$ & $\begin{array}{l}\text { After stool transplantation from } \\
\text { depression patients to germ-free } \\
\text { mice started to show } \\
\text { depression-like behaviors. }\end{array}$ & Zheng et al. [116] \\
\hline $\begin{array}{l}\text { Patients with major } \\
\text { depression and healthy } \\
\text { subjects, adult male } \\
\text { Sprague-Dawley rats }\end{array}$ & $\begin{array}{l}\text { Plasma C-reactive protein, panel of } \\
\text { cytokines, salivary cortisol levels, } \\
\text { plasma tryptophan and kynurenine, } \\
\text { plasma lipopolysaccharide binding } \\
\text { protein, 16sRNA metagenomic } \\
\text { sequencing for fecal samples }\end{array}$ & $\begin{array}{l}\text { After fecal microbiota } \\
\text { transplantation from depressed } \\
\text { persons to rats, depression- and } \\
\text { anxiety-like behaviors were } \\
\text { observed in the laboratory animals. }\end{array}$ & Kelly et al. [117] \\
\hline
\end{tabular}

\section{Conclusions}

The philosopher of science Thomas Samuel Kuhn defined the concept of "paradigm shift" in his book The Structure of Scientific Revolutions [124]. Evidence presented in recent years indicates that modern psychopharmacology has been undergoing a significant paradigm shift in the last 70 years, resulting in significant progress in the study of the pathophysiology and treatment of neuropsychiatric disorders. Although the mechanisms have not yet been elucidated, the intestinal microbiota appear to play a role in the development of neuropsychiatric disorders. The research to date suggests that microbiota-based treatment can positively affect synaptic functioning. Although there exists some promising evidence for this, there are still many questions to be answered. Numerous randomized controlled trials are required to obtain these answers.

Author Contributions: Conceptualization, A.E., B.Ö.Ü. and M.E.C.; Methodology, A.E., B.Ö.Ü. and M.E.C.; Software, A.E., B.Ö.Ü. and M.E.C.; Validation, A.E., B.Ö.Ü. and M.E.C.; Formal Analysis, A.E., B.Ö.Ü. and M.E.C.; Investigation, A.E., B.Ö.Ü. and M.E.C.; Resources, A.E., B.Ö.Ü. and M.E.C.; Data Curation, A.E., B.Ö.Ü. and M.E.C.; Writing-Original Draft Preparation, A.E., B.Ö.Ü. and M.E.C.; Writing-Review \& Editing, A.E., B.Ö.Ü. and M.E.C.; Visualization, A.E., B.Ö.Ü. and M.E.C.; Supervision, A.E., B.Ö.Ü. and M.E.C.; Project Administration, A.E., B.Ö.Ü. and M.E.C.

Funding: This research received no external funding.

Conflicts of Interest: The authors declare no conflict of interest.

\section{References}

1. Ban, T.A. Fifty years chlorpromazine: A historical perspective. Neuropsychiatr. Dis. Treat. 2007, 3, 495-500. [PubMed]

2. Ban, T.A. Pharmacotherapy of mental illness. A historical analysis. Prog. Neuropsychopharmacol. Biol. Psychiatry 2001, 25, 709-727. [CrossRef]

3. Bennett, M.R. Monoaminergic synapses and schizophrenia: 45 years of neuroleptics. J. Psychopharmacol. 1998, 12, 289-304. [CrossRef] [PubMed]

4. Evrensel, A.; Önen Ünsalver, B.; Ceylan, M.E. Gut-Brain Axis and Psychiatric Disorders. Curr. Psych. Rev. 2018, 14, 178-186. [CrossRef]

5. Spohn, S.N.; Mawe, G.M. Non-conventional features of peripheral serotonin signaling-The gut and beyond. Nat. Rev. Gastroenterol. Hepatol. 2017, 14, 412-420. [CrossRef] [PubMed]

6. Gardner, A.; Boles, R.G. Is a "mitochondrial psychiatry" in the future? A review. Curr. Psych. Rev. 2005, 1, 255-271. [CrossRef] 
7. Gardner, A.; Boles, R.G. Beyond the serotonin hypothesis: Mitochondria, inflammation and neurodegeneration in major depression and affective spectrum disorders. Prog. Neuropsychopharmacol. Biol. Psychiatry 2011, 35, 730-743. [CrossRef]

8. Han, B.; Sivaramakrishnan, P.; Lin, C.J.; Neve, I.A.A.; He, J.; Tay, L.W.R.; Sowa, J.N.; Sizovs, A.; Du, G.; Wang, J.; et al. Microbial genetic composition tunes host longevity. Cell 2017, 169, 1249-1262. [CrossRef]

9. Wu, H.; Denna, T.H.; Storkersen, J.N.; Gerriets, V.A. Beyond a neurotransmitter: The role of serotonin in inflammation and immunity. Pharmacol. Res. 2018, 6618, 30301-30303. [CrossRef]

10. Anderson, G. Linking the biological underpinnings of depression: Role of mitochondria interactions with melatonin, inflammation, sirtuins, tryptophan catabolites, DNA repair and oxidative and nitrosative stress, with consequences for classification and cognition. Prog. Neuropsychopharmacol. Biol. Psychiatry 2018, 80, 255-266. [CrossRef]

11. Whitman, W.B.; Coleman, D.C.; Wiebe, W.J. Prokaryotes: The unseen majority. Proc. Natl. Acad. Sci. USA 1998, 95, 6578-6583. [CrossRef] [PubMed]

12. Evrensel, A.; Ceylan, M.E. Gut-Microbiota-Brain Axis and Depression. In Understanding Depression; Kim, Y.K., Ed.; Springer: Singapore, 2018; pp. 197-207.

13. Rieder, R.; Wisniewski, P.J.; Alderman, B.L.; Campbell, S.C. Microbes and mental health: A review. Brain Behav. Immun. 2017, 66, 9-17. [CrossRef]

14. Abisado, R.G.; Benomar, S.; Klaus, J.R.; Dandekar, A.A.; Chandler, J.R. Bacterial quorum sensing and microbial community interactions. MBio 2018, 9, e02331-17. [CrossRef] [PubMed]

15. Dinan, T.G.; Stilling, R.M.; Stanton, C.; Cryan, J.F. Collective unconscious: How gut microbes shape human behavior. J. Psychiatr. Res. 2015, 63, 1-9. [CrossRef] [PubMed]

16. Branton, W.G.; Ellestad, K.K.; Maingat, F.; Wheatley, B.M.; Rud, E.; Warren, R.L.; Holt, R.A.; Surette, M.G.; Power, C. Brain microbial populations in HIV/AIDS: $\alpha$-proteobacteria predominate independent of host immune status. PLoS ONE 2013, 8, e54673. [CrossRef] [PubMed]

17. Roberts, R.C.; Farmer, C.B.; Walker, C.K. Psychiatry and Behavioral Neurobio., Univ. of Alabama, Birmingham, Birmingham, AL. In The Human Brain Microbiome; There Are Bacteria in Our Brains! Program No. 594.08. 2018 Neuroscience Meeting Planner; Society for Neuroscience: San Diego, CA, USA, 2018.

18. Evrensel, A.; Ceylan, M.E. The gut-brain axis: The missing link in depression. Clin. Psychopharmacol. Neurosci. 2015, 13, 239-244. [CrossRef] [PubMed]

19. Sender, R.; Fuchs, S.; Milo, R. Revised estimates for the number of human and bacteria cells in the body. PLoS Biol. 2016, 14, e1002533. [CrossRef]

20. Lozupone, C.A.; Stombaugh, J.I.; Gordon, J.I.; Jansson, J.K.; Knight, R. Diversity, stability and resilience of the human gut microbiota. Nature 2012, 489, 220-230. [CrossRef]

21. Enaud, R.; Vandenborght, L.E.; Coron, N.; Bazin, T.; Prevel, R.; Schaeverbeke, T.; Berger, P.; Fayon, M.; Lamireau, T.; Delhaes, L. The Mycobiome: A Neglected Component in the Microbiota-Gut-Brain Axis. Microorganisms 2018, 6, 22. [CrossRef]

22. Mariat, D.; Firmesse, O.; Levenez, F.; Guimarăes, V.; Sokol, H.; Doré, J.; Corthier, G.; Furet, J.P. The Firmicutes/Bacteroidetes ratio of the human microbiota changes with age. BMC Microbiol. 2009, 9, 123. [CrossRef]

23. David, L.A.; Maurice, C.F.; Carmody, R.N.; Gootenberg, D.B.; Button, J.E.; Wolfe, B.E.; Ling, A.V.; Devlin, A.S.; Varma, Y.; Fischbach, M.A.; et al. Diet rapidly and reproducibly alters the human gut microbiome. Nature 2014, 505, 559-563. [CrossRef]

24. Dash, S.; Clarke, G.; Berk, M.; Jacka, F.N. The gut microbiome and diet in psychiatry: Focus on depression. Curr. Opin. Psychiatry 2015, 28, 16. [CrossRef] [PubMed]

25. Macedo, D.; Filho, A.J.M.C.; Soares de Sousa, C.N.; Quevedo, J.; Barichello, T.; Júnior, H.V.N.; Freitas de Lucena, D. Antidepressants, antimicrobials or both? Gut microbiota dysbiosis in depression and possible implications of the antimicrobial effects of antidepressant drugs for antidepressant effectiveness. J. Affect. Disord. 2017, 208, 22-32. [CrossRef] [PubMed]

26. Davey, K.J.; O’Mahony, S.M.; Schellekens, H.; O'Sullivan, O.; Bienenstock, J.; Cotter, P.D.; Dinan, T.G.; Cryan, J.F. Olanzapine induced weight gain in the rat: Impact on inflammatory, metabolic and microbiota parameters. Psychopharmacology 2013, 221, 155-169. [CrossRef] [PubMed]

27. Bailey, M.T.; Coe, C.L. Maternal separation disrupts the integrity of the intestinal microflora in infant rhesus monkeys. Dev. Psychobiol. 1999, 35, 146-155. [CrossRef] 
28. O'Mahony, S.M.; Marchesi, J.R.; Scully, P.; Codling, C.; Ceolho, A.M.; Quigley, E.M.; Cryan, J.F.; Dinan, T.G. Early life stress alters behavior, immunity, and microbiota in rats: Implications for irritable bowel syndrome and psychiatric illnesses. Biol. Psychiatry 2009, 65, 263-267. [CrossRef] [PubMed]

29. Bailey, M.T.; Dowd, S.E.; Galley, J.D.; Hufnagle, A.R.; Allen, R.G.; Lyte, M. Exposure to a social stressor alters the structure of the intestinal microbiota: Implications for stressor-induced immunomodulation. Brain Behav. Immun. 2011, 25, 397-407. [CrossRef] [PubMed]

30. Gárate, I.; García-Bueno, B.; Madrigal, J.L.; Bravo, L.; Berrocoso, E.; Caso, J.R.; Micó, J.A.; Leza, J.C. Origin and consequences of brain toll-like receptor 4 pathway stimulation in an experimental model of depression. J. Neuroinflamm. 2011, 8, 151. [CrossRef]

31. Slykerman, R.F.; Thompson, J.; Waldie, K.E.; Murphy, R.; Wall, C.; Mitchell, E.A. Antibiotics in the first year of life and subsequent neurocognitive outcomes. Acta Paediatr. 2017, 106, 87-94. [CrossRef]

32. Desbonnet, L.; Clarke, G.; Traplin, A.; O'Sullivan, O.; Crispie, F.; Moloney, R.D.; Cotter, P.D.; Dinan, T.G.; Cryan, J.F. Gut microbiota depletion from early adolescence in mice: Implications for brain and behavior. Brain Behav. Immun. 2015, 48, 165-173. [CrossRef]

33. Liu, F.; Guo, X.; Wu, R.; Ou, J.; Zheng, Y.; Zhang, B.; Xie, L.; Zhang, L.; Yang, L.; Yang, S.; et al. Minocycline supplementation for treatment of negative symptoms in early-phase schizophrenia: A double blind, randomized, controlled trial. Schizophr. Res. 2014, 153, 169-176. [CrossRef] [PubMed]

34. Scott, K.A.; Ida, M.; Peterson, V.L.; Prenderville, J.A.; Moloney, G.M.; Izumo, T.; Murphy, K.; Murphy, A.; Ross, R.P.; Stanton, C.; et al. Revisiting Metchnikoff: Age-related alterations in microbiota-gut-brain axis in the mouse. Brain Behav. Immun. 2017, 65, 20-32. [CrossRef] [PubMed]

35. Phillips, J. The treatment of melancholia by the lactic acid bacillus. J. Mental. Sci. 1910, 56, 422-430. [CrossRef]

36. Strachan, D.P. Hay fever, hygiene, and household size. Br. Med. J. 1989, 299, 1259-1260. [CrossRef]

37. Rook, G.A. 99th Dahlem conference on infection, inflammation and chronic inflammatory disorders: Darwinian medicine and the 'hygiene' or 'old friends' hypothesis. Clin. Exp. Immunol. 2010, 160, 70-79. [CrossRef] [PubMed]

38. Rook, G.A.; Lowry, C.A.; Raison, C.L. Hygiene and early childhood influences on the subsequent function of the immune system. Brain Res. 2015, 1617, 47-62. [CrossRef] [PubMed]

39. Evrensel, A.; Ceylan, M.E. Microbiome: The missing link in neuropsychiatric disorders. EMJ. Innov. 2017, 1, 83-88.

40. Evrensel, A.; Ceylan, M.E. Fecal Microbiota Transplantation in the Treatment-Resistant Psychiatric Disorders in Treatment Resistance in Psychiatry; Kim, Y.K., Ed.; Springer: Singapore, 2019; pp. 369-376.

41. Steel, Z.; Marnane, C.; Iranpour, C.; Chey, T.; Jackson, J.W.; Patel, V.; Silove, D. The global prevalence of common mental disorders: A systematic review and meta-analysis 1980-2013. Int. J. Epidemiol. 2014, 43, 476-493. [CrossRef]

42. Charlson, F.J.; Ferrari, A.J.; Santomauro, D.F.; Diminic, S.; Stockings, E.; Scott, J.G.; McGrath, J.J.; Whiteford, H.A. Global Epidemiology and Burden of Schizophrenia: Findings from the Global Burden of Disease Study 2016. Schizophr. Bull. 2018, 44, 1195-1203. [CrossRef]

43. Kogan, M.D.; Vladutiu, C.J.; Schieve, L.A.; Ghandour, R.M.; Blumberg, S.J.; Zablotsky, B.; Perrin, J.M.; Shattuck, P.; Kuhlthau, K.A.; Harwood, R.L.; et al. The Prevalence of Parent-Reported Autism Spectrum Disorder Among US Children. Pediatrics 2018, 142, e20174161. [CrossRef]

44. Zopf, Y.; Reljic, D.; Dieterich, W. Dietary Effects on Microbiota-New Trends with Gluten-Free or Paleo Diet. Med. Sci. (Basel) 2018, 6, 92. [CrossRef] [PubMed]

45. Taylor, A.M.; Holscher, H.D. A review of dietary and microbial connections to depression, anxiety, and stress. Nutr. Neurosci. 2018, 1-14. [CrossRef] [PubMed]

46. Dinan, T.G.; Stanton, C.; Cryan, J.F. Psychobiotics: A novel class of psychotropic. Biol. Psychiatry 2013, 74, 720-726. [CrossRef] [PubMed]

47. Maes, M.; Kubera, M.; Leunis, J.C.; Berk, M. Increased IgA and IgM responses against gut commensals in chronic depression: Further evidence for increased bacterial translocation or leaky gut. J. Affect. Disord. 2012, 141, 55-62. [CrossRef] [PubMed]

48. Ait-Belgnaoui, A.; Durand, H.; Cartier, C.; Chaumaz, G.; Eutamene, H.; Ferrier, L.; Houdeau, E.; Fioramonti, J.; Bueno, L.; Theodorou, V. Prevention of gut leakiness by a probiotic treatment leads to attenuated HPA response to an acute psychological stress in rats. Psychoneuroendocrinology 2012, 37, 1885-1895. [CrossRef] 
49. De Theije, C.G.M.; Wopereis, H.; Ramadan, M.; van Eijndthoven, T.; Lambert, J.; Knol, J.; Garssen, J.; Kraneveld, A.D.; Oozeer, R. Altered gut microbiota and activity in a murine model of autism spectrum disorders. Brain Behav. Immun. 2014, 37, 197-206. [CrossRef]

50. De Theije, C.G.M.; Koelink, P.J.; Korte-Bouws, G.A.H.; Lopes da Silva, S.; Korte, S.M.; Olivier, B.; Garssen, J.; Kraneveld, A.D. Intestinal inflammation in a murine model of autism spectrum disorders. Brain Behav. Immun. 2014, 37, 240-247. [CrossRef]

51. Zareie, M.; Johnson-Henry, K.; Jury, J.; Yang, P.C.; Ngan, B.Y.; McKay, D.M.; Soderholm, J.D.; Perdue, M.H.; Sherman, P.M. Probiotics prevent bacterial translocation and improve intestinal barrier function in rats following chronic psychological stress. Gut 2006, 55, 1553-1560. [CrossRef]

52. Reandon, S. Gut-brain link grabs neuroscientists. Nature 2014, 515, 175-177. [CrossRef]

53. Hsiao, E.Y.; McBride, S.W.; Hsien, S.; Sharon, G.; Hyde, E.R.; McCue, T.; Codelli, J.A.; Chow, J.; Reisman, S.E.; Petrosino, J.F.; et al. Microbiota modulate behavioral and physiological abnormalities associated with neurodevelopmental disorders. Cell 2013, 155, 1451-1463. [CrossRef]

54. Messaoudi, M.; Lalonde, R.; Violle, N.; Javelot, H.; Desor, D.; Nejdi, A.; Bisson, J.F.; Rougeot, C.; Pichelin, M.; Cazaubiel, M.; et al. Assessment of psychotropic-like properties of a probiotic formulation (Lactobacillus helveticus R0052 and Bifidobacterium longum R0175) in rats and human subjects. Br. J. Nutr. 2011, 105, 755-764. [CrossRef]

55. Schmidt, K.; Cowen, P.J.; Harmer, C.J.; Tzortzis, G.; Errington, S.; Burnet, P.W. Prebiotic intake reduces the waking cortisol response and alters emotional bias in healthy volunteers. Psychopharmacology 2015, 232, 1793-1801. [CrossRef] [PubMed]

56. Chu, H.; Mazmanian, S.K. Innate immune recognition of the microbiota promotes host-microbial symbiosis. Nat. Immunol. 2013, 14, 668-675. [CrossRef] [PubMed]

57. O’Mahony, L.; McCarthy, J.; Kelly, P.; Hurley, G.; Luo, F.; Chen, K.; O'Sullivan, G.C.; Kiely, B.; Collins, J.K.; Shanahan, F.; et al. Lactobacillus and Bifidobacterium in irritable bowel syndrome: Symptom responses and relationship to cytokine profiles. Gastroenterology 2005, 128, 541-551. [CrossRef] [PubMed]

58. Zhou, W.; Lv, H.; Li, M.X.; Su, H.; Huang, L.G.; Li, J.; Yuan, W.M. Protective effects of bifidobacteria on intestines in newborn rats with necrotizing enterocolitis and its regulation on TLR2 and TLR4. Genet. Mol. Res. 2015, 14, 11505-11514. [CrossRef] [PubMed]

59. Louveau, A.; Smirnov, I.; Keyes, T.J.; Eccles, J.D.; Rouhani, S.J.; Peske, J.D. Structural and functional features of central nervous system lymphatic vessels. Nature 2015, 523, 337-341. [CrossRef] [PubMed]

60. Miller, A.H.; Haroon, E.; Raison, C.L.; Felger, J.C. Cytokine targets in the brain: Impact on neurotransmitters and neurocircuits. Depress. Anxiety 2013, 30, 297-306. [CrossRef]

61. Felger, J.C.; Lotrich, F.E. Inflammatory cytokines in depression: Neurobiological mechanisms and therapeutic implications. Neuroscience 2013, 246, 199-229. [CrossRef]

62. Bercik, P.; Verdu, E.F.; Foster, J.A.; Macri, J.; Potter, M.; Huang, X.; Malinowski, P.; Jackson, W.; Blennerhassett, P.; Neufeld, K.A.; et al. Chronic gastrointestinal inflammation induces anxiety-like behavior and alters central nervous system biochemistry in mice. Gastroenterology 2010, 139, 2102-2112. [CrossRef]

63. Sudo, N.; Chida, Y.; Aiba, Y.; Sonoda, J.; Oyama, N.; Yu, X.N.; Kubo, C.; Koga, Y. Postnatal microbial colonization programs the hypothalamic-pituitary-adrenal system for stress response in mice. J. Physiol. 2004, 558, 263-275. [CrossRef]

64. Messaoudi, M.; Violle, N.; Bisson, J.F.; Desor, D.; Javelot, H.; Rougeot, C. Beneficial psychological effects of a probiotic formulation (Lactobacillus helveticus R0052 and Bifidobacterium longum R0175) in healthy human volunteers. Gut Microbes 2011, 2, 256-261. [CrossRef] [PubMed]

65. Foster, J.A.; McVey Neufeld, K.A. Gut-brain axis: How the microbiome influences anxiety and depression. Trends Neurosci. 2013, 36, 305-312. [CrossRef] [PubMed]

66. Bercik, P.; Park, A.J.; Sinclair, D.; Khoshdel, A.; Lu, J.; Huang, X.; Deng, Y.; Blennerhassett, P.A.; Fahnestock, M.; Moine, D.; et al. The anxiolytic effect of Bifidobacterium longum NCC3001 involves vagal pathways for gut-brain communication. Neurogastroenterol. Motil. 2011, 23, 1132-1139. [CrossRef] [PubMed]

67. Мa, X.; Mao, Y.K.; Wang, B.; Huizinga, J.D.; Bienenstock, J.; Kunze, W. Lactobacillus reuteri ingestion prevents hyperexcitability of colonic DRG neurons induced by noxious stimuli. Am. J. Physiol. Gastrointest. Liver Physiol. 2009, 296, G868-G875. [CrossRef] [PubMed] 
68. Lomasney, K.W.; Houston, A.; Shanahan, F.; Dinan, T.G.; Cryan, J.F.; Hyland, N.P. Selective influence of host micro-biota on cAMP-mediated ion transport in mouse colon. Neurogastroenterol. Motil. 2014, 26, 887-888. [CrossRef] [PubMed]

69. Kabouridis, P.S.; Lasrado, R.; McCallum, S.; Chng, S.H.; Snippert, H.J.; Clevers, H.; Pettersson, S.; Pachnis, V. Microbiota controls the homeostasis of glial cells in the gut lamina propria. Neuron 2015, 85, 289-295. [CrossRef] [PubMed]

70. McVey Neufeld, K.A.; Mao, Y.K.; Bienenstock, J.; Foster, J.A.; Kunze, W.A. The microbiome is essential for normal gut intrinsic primary afferent neuron excitability in the mouse. Neurogastroenterol. Motil. 2013, 25, 183-188. [CrossRef]

71. Collins, J.; Borojevic, R.; Verdu, E.F.; Huizinga, J.D.; Ratcliffe, E.M. Intestinal microbiota influence the early postnatal development of the enteric nervous system. Neurogastroenterol. Motil. 2014, 26, 98-107. [CrossRef]

72. Bonaz, B.; Sinniger, V.; Pellissier, S. The vagus nerve in the neuro-immune axis: Implications in the pathology of the gastrointestinal tract. Front. Immunol. 2017, 8, 1452. [CrossRef]

73. Mezzacappa, E.S.; Kelsey, R.M.; Katkin, E.S.; Sloan, R.P. Vagal rebound and recovery from psychological stress. Psychosom. Med. 2001, 63, 650-657. [CrossRef]

74. De Haan, J.J.; Hadfoune, M.; Lubbers, T.; Hodin, C.; Lenaerts, K.; Ito, A.; Verbaeys, I.; Skynner, M.J.; Cailotto, C.; van der Vliet, J.; et al. Lipid-rich enteral nutrition regulates mucosal mast cell activation via the vagal anti-inflammatory reflex. Am. J. Physiol. Gastrointest. Liver Physiol. 2013, 305, G383-G391. [CrossRef] [PubMed]

75. Weberruss, H.; Maucher, J.; Oberhoffer, R.; Müller, J. Recovery of the cardiac autonomic nervous and vascular system after maximal cardiopulmonary exercise testing in recreational athletes. Eur. J. Appl. Physiol. 2018, 118, 205-211. [CrossRef] [PubMed]

76. Kirchner, A.; Birklein, F.; Stefan, H.; Handwerker, H.O. Left vagus nerve stimulation suppresses experimentally induced pain. Neurology 2000, 55, 1167-1171. [CrossRef] [PubMed]

77. Shah, A.P.; Carreno, F.R.; Wu, H.; Chung, Y.A.; Frazer, A. Role of TrkB in the anxiolytic-like and antidepressant-like effects of vagal nerve stimulation: Comparison with desipramine. Neuroscience 2016, 322, 273-286. [CrossRef] [PubMed]

78. Galbarriatu, L.; Pomposo, I.; Aurrecoechea, J.; Marinas, A.; Agúndez, M.; Gómez, J.C.; Acera, M.A.; Martínez, M.J.; Valle, E.; Maestro, I.; et al. Vagus nerve stimulation therapy for treatment-resistant epilepsy: A 15-year experience at a single institution. Clin. Neurol. Neurosurg. 2015, 137, 89-93. [CrossRef] [PubMed]

79. Abdel Salam, O.M. Fluoxetine and sertraline stimulate gastric acid secretion via a vagal pathway in anaesthetised rats. Pharmacol. Res. 2004, 50, 309-316. [CrossRef] [PubMed]

80. Bercik, P.; Denou, E.; Collins, J.; Jackson, W.; Lu, J.; Jury, J.; Deng, Y.; Blennerhassett, P.; Macri, J.; McCoy, K.D.; et al. The intestinal microbiota affect central levels of brain-derived neurotropic factor and behavior in mice. Gastroenterology 2011, 141, 599-609. [CrossRef] [PubMed]

81. Malick, M.; Gilbert, K.; Daniel, J.; Arseneault-Breard, J.; Tompkins, T.A.; Godbout, R.; Rousseau, G. Vagotomy prevents the effect of probiotics on caspase activity in a model of postmyocardial infarction depression. Neurogastroenterol. Motil. 2015, 27, 663-671. [CrossRef]

82. Qin, J.; Li, R.; Raes, J.; Arumugam, M.; Burgdorf, K.S.; Manichanh, C.; Nielsen, T.; Pons, N.; Levenez, F.; Yamada, T.; et al. A human gut microbial gene catalogue established by metagenomic sequencing. Nature 2010, 464, 59-65. [CrossRef]

83. Tan, J.; McKenzie, C.; Potamitis, M.; Thorburn, A.N.; Mackay, C.R.; Macia, L. The role of short-chain fatty acids in health and disease. Adv. Immunol. 2014, 121, 91-119.

84. Lei, E.; Vacy, K.; Boon, W.C. Fatty acids and their therapeutic potential in neurological disorders. Neurochem. Int. 2016, 95, 75-84. [CrossRef] [PubMed]

85. Sun, J.; Wang, F.; Hong, G.; Pang, M.; Xu, H.; Li, H.; Tian, F.; Fang, R.; Yao, Y.; Liu, J. Antidepressant-like effects of sodium butyrate and its possible mechanisms of action in mice exposed to chronic unpredictable mild stress. Neurosci. Lett. 2016, 618, 159-166. [CrossRef] [PubMed]

86. Stilling, R.M.; Dinan, T.G.; Cryan, J.F. Microbial genes, brain \& behaviour-epigenetic regulation of the gut-brain axis. Genes Brain Behav. 2014, 13, 69-86. [PubMed]

87. Erny, D.; Hrabě de Angelis, A.L.; Jaitin, D.; Wieghofer, P.; Staszewski, O.; David, E.; Keren-Shaul, H.; Mahlakoiv, T.; Jakobshagen, K.; Buch, T.; et al. Host microbiota constantly control maturation and function of microglia in the CNS. Nat. Neurosci. 2015, 18, 965-977. [CrossRef] [PubMed] 
88. Morris, G.; Berk, M.; Carvalho, A.; Caso, J.R.; Sanz, Y.; Walder, K.; Maes, M. The Role of the Microbial Metabolites Including Tryptophan Catabolites and Short Chain Fatty Acids in the Pathophysiology of Immune-Inflammatory and Neuroimmune Disease. Mol. Neurobiol. 2017, 54, 4432-4451. [CrossRef] [PubMed]

89. Wikoff, W.R.; Anfora, A.T.; Liu, J.; Schultz, P.G.; Lesley, S.A.; Peters, E.C.; Siuzdak, G. Metabolomics analysis reveals large effects of gut microflora on mammalian blood metabolites. Proc. Natl. Acad. Sci. USA 2009, 106, 3698-3703. [CrossRef] [PubMed]

90. Neufeld, K.A.; Kang, N.; Bienenstock, J.; Foster, J.A. Effects of intestinal microbiota on anxiety-like behavior. Commun. Integr. Biol. 2011, 4, 492-494. [CrossRef] [PubMed]

91. Lyte, M. Probiotics function mechanistically as delivery vehicles for neuroactive compounds: Microbial endocrinology in the design and use of probiotics. Bioessays 2011, 33, 574-581. [CrossRef] [PubMed]

92. Diaz Heijtz, R.; Wang, S.; Anuar, F.; Qian, Y.; Björkholm, B.; Samuelsson, A.; Hibberd, M.L.; Forssberg, H.; Pettersson, S. Normal gut microbiota modulates brain development and behavior. Proc. Natl. Acad. Sci. USA 2011, 108, 3047-3052. [CrossRef]

93. Desbonnet, L.; Garrett, L.; Clarke, G.; Bienenstock, J.; Dinan, T.G. The probiotic Bifidobacteria infantis: An assessment of potential antidepressant properties in the rat. J. Psychiatr. Res. 2008, 43, 164-174. [CrossRef]

94. Desbonnet, L.; Garrett, L.; Clarke, G.; Kiely, B.; Cryan, J.F.; Dinan, T.G. Effects of the probiotic Bifidobacterium infantis in the maternal separation model of depression. Neuroscience 2010, 170, 1179-1188. [CrossRef] [PubMed]

95. Moya-Perez, A.; Perez-Villalba, A.; Benitez-Paez, A.; Campillo, I.; Sanz, Y. Bifidobacterium CECT 7765 modulates early stress-induced immune, neuroendocrine and behavioral alterations in mice. Brain. Behav. Immun. 2017, 65, 43-56. [CrossRef] [PubMed]

96. Bravo, J.A.; Forsythe, P.; Chew, M.V.; Escaravage, E.; Savignac, H.M.; Dinan, T.G.; Bienenstock, J.; Cryan, J.F. Ingestion of Lactobacillus strain regulates emotional behavior and central GABA receptor expression in a mouse via the vagus nerve. Proc. Natl. Acad. Sci. USA 2011, 108, 16050-16055. [CrossRef] [PubMed]

97. Janik, R.; Thomason, L.A.M.; Stanisz, A.M.; Forsythe, P.; Bienenstock, J.; Stanisz, G.J. Magnetic resonance spectroscopy reveals oral Lactobacillus promotion of increases in brain GABA, $N$-acetyl aspartate and glutamate. Neuroimage 2016, 125, 988-995. [CrossRef] [PubMed]

98. Liang, S.; Wang, T.; Hu, X.; Luo, J.; Li, W.; Wu, X.; Duan, Y.; Jin, F. Administration of Lactobacillus helveticus NS8 improves behavioral, cognitive, and biochemical aberrations caused by chronic restraint stress. Neuroscience 2015, 310, 561-577. [CrossRef] [PubMed]

99. McVey Neufeld, K.A.; Kay, S.; Bienenstock, J. Mouse strain affects behavioral and neuroendocrine stress responses following administration of probiotic Lactobacillus rhamnosus JB-1 or traditional antidepressant fluoxetine. Front. Neurosci. 2018, 12, 294. [CrossRef] [PubMed]

100. Benton, D.; Williams, C.; Brown, A. Impact of consuming a milk drink containing a probiotic on mood and cognition. Eur. J. Clin. Nutr. 2007, 61, 355-361. [CrossRef]

101. Allen, A.P.; Hutch, W.; Borre, Y.E.; Kennedy, P.J.; Temko, A.; Boylan, G.; Murphy, E.; Cryan, J.F.; Dinan, T.G.; Clarke, G. Bifidobacterium longum 1714 as a translational psychobiotic: Modulation of stress, electrophysiology and neurocognition in healthy volunteers. Transl. Psychiatry 2016, 6, e939. [CrossRef]

102. Naseribafrouei, A.; Hestad, K.; Avershina, E.; Sekelja, M.; Linløkken, A.; Wilson, R.; Rudi, K. Correlation between the human fecal microbiota and depression. Neurogastroenterol. Motil. 2014, 26, 1155-1162. [CrossRef]

103. Kato-Kataoka, A.; Nishida, K.; Takada, M.; Kawai, M.; Kikuchi-Hayakawa, H.; Suda, K.; Ishikawa, H.; Gondo, Y.; Shimizu, K.; Matsuki, T.; et al. Fermented milk containing Lactobacillus casei strain Shirota preserves the diversity of the gut microbiota and relieves abdominal dysfunction in healthy medical students exposed to academic stress. Appl. Environ. Microbiol. 2016, 82, 3649-3658. [CrossRef]

104. Sashihara, T.; Nagata, M.; Mori, T.; Ikegami, S.; Gotoh, M.; Okubo, K.; Uchida, M.; Itoh, H. Effects of Lactobacillus gasseri OLL2809 and $\alpha$-lactalbumin on university-student athletes: A randomized, double-blind, placebo-controlled clinical trial. Appl. Physiol. Nutr. Metabol. 2013, 38, 1228-1235. [CrossRef]

105. Tillisch, K.; Labus, J.; Kilpatrick, L.; Jiang, Z.; Stains, J.; Ebrat, B.; Guyonnet, D.; Legrain-Raspaud, S.; Trotin, B.; Naliboff, B.; et al. Consumption of fermented milk product with probiotic modulates brain activity. Gastroenterology 2013, 144, 1394-1401. [CrossRef] [PubMed] 
106. Pinto-Sanchez, M.I.; Hall, G.B.; Ghajar, K.; Nardelli, A.; Bolino, C.; Lau, J.T.; Martin, F.P.; Cominetti, O.; Welsh, C.; Rieder, A.; et al. Probiotic Bifidobacterium longum NCC3001 reduces depression scores and alters brain activity: A pilot study in patients with irritable bowel syndrome. Gastroenterology 2017, 153, 448-459. [CrossRef] [PubMed]

107. Kelly, J.R.; Allen, A.P.; Temko, A.; Hutch, W.; Kennedy, P.J.; Farid, N.; Murphy, E.; Boylan, G.; Bienenstock, J.; Cryan, J.F.; et al. Lost in translation? The potential psychobiotic Lactobacillus rhamnosus (JB-1) fails to modulate stress or cognitive performance in healthy male subjects. Brain Behav. Immun. 2017, 61, 50-59. [CrossRef] [PubMed]

108. Macfarlane, S.; Macfarlane, G.T. Regulation of short-chain fatty acid production. Proc. Nutr. Soc. 2003, 62, 67-72. [CrossRef] [PubMed]

109. Bollrath, J.; Powrie, F. Immunology. Feed your Tregs more fiber. Science 2013, 341, 463-464. [CrossRef] [PubMed]

110. López-Muñoz, F.; Alamo, C. Monoaminergic neurotransmission: The history of the discovery of antidepressants from 1950s until today. Curr. Pharm. Des. 2009, 15, 1563-1586. [CrossRef]

111. Ishijima, S.A.; Abe, S. A novel murine candidiasis model with severe colonization in the stomach induced by $\mathrm{N}$-acetylglucosamine-treatment and its scoring system based on local characteristic stomach symptoms. Med. Mycol. J. 2015, 56, E31-E39. [CrossRef]

112. Evrensel, A.; Ceylan, M.E. Fecal microbiota transplantation and its usage in neuropsychiatric disorders. Clin. Psychopharmacol. Neurosci. 2016, 14, 231-237. [CrossRef]

113. Jiang, H.; Ling, Z.; Zhang, Y.; Mao, H.; Ma, Z.; Yin, Y.; Wang, W.; Tang, W.; Tan, Z.; Shi, J.; et al. Altered fecal microbiota composition in patients with major depressive disorder. Brain Behav. Immun. 2015, 48, 186-194. [CrossRef]

114. Schwarz, E.; Maukonen, J.; Hyytiäinen, T.; Kieseppä, T.; Orešič, M.; Sabunciyan, S.; Mantere, O.; Saarela, M.; Yolken, R.; Suvisaari, J. Analysis of microbiota in first episode psychosis identifies preliminary associations with symptom severity and treatment response. Schizoph. Res. 2018, 192, 398-403. [CrossRef] [PubMed]

115. Zheng, P.; Zeng, B.; Zhou, C.; Liu, M.; Fang, Z.; Xu, X.; Zeng, L.; Chen, J.; Fan, S.; Du, X.; et al. Gut microbiome remodeling induces depressive-like behaviors through a pathway mediated by the host's metabolism. Mol. Psychiatry 2016, 21, 786-796. [CrossRef] [PubMed]

116. Kelly, J.R.; Borre, Y.; O’Brien, C.; Patterson, E.; El Aidy, S.; Deane, J.; Kennedy, P.; Beers, S.; Scott, K.; Moloney, G.; et al. Transferring the blues: Depression-associated gut microbiota induces neurobehavioural changes in the rat. J. Psychiatr. Res. 2016, 82, 109-118. [CrossRef]

117. Aroniadis, O.C.; Brandt, L.J. Fecal microbiota transplantation: Past, present and future. Curr. Opin. Gastroenterol. 2013, 29, 79-84. [CrossRef] [PubMed]

118. Kang, D.W.; Adams, J.B.; Gregory, A.C.; Borody, T.; Chittick, L.; Fasano, A.; Khoruts, A.; Geis, E.; Maldonado, J.; McDonough-Means, S.; et al. Microbiota Transfer Therapy alters gut ecosystem and improves gastrointestinal and autism symptoms: An open-label study. Microbiome 2017, 5, 10. [CrossRef] [PubMed]

119. Brandt, L.J.; Aroniadis, O.C.; Mellow, M.; Kanatzar, A.; Kelly, C.; Park, T.; Stollman, N.; Rohlke, F.; Surawicz, C. Long-term follow-up of colonoscopic fecal microbiota transplantation for recurrent Clostridium difficile infection. Am. J. Gastroenterol. 2012, 107, 1079-1087. [CrossRef] [PubMed]

120. Smits, L.P.; Bouter, K.E.; de Vos, W.M.; Borody, T.J.; Nieuwdorp, M. Therapeutic potential of fecal microbiota transplantation. Gastroenterology 2013, 145, 946-953. [CrossRef]

121. Gough, E.; Shaikh, H.; Manges, A.R. Systematic review of intestinal microbiota transplantation (fecal bacteriotherapy) for recurrent Clostridium difficile infection. Clin. Infect. Dis. 2011, 53, 994-1002. [CrossRef]

122. De Leon, L.M.; Watson, J.B.; Kelly, C.R. Transient flare of ulcerative colitis after fecal microbiota transplantation for recurrent Clostridium difficile infection. Clin. Gastroenterol. Hepatol. 2013, 11, 1036-1038. [CrossRef]

123. Aas, J.; Gessert, C.E.; Bakken, J.S. Recurrent Clostridium difficile colitis: Case series involving 18 patients treated with donor stool administered via a nasogastric tube. Clin. Infect. Dis. 2003, 36, 580-585. [CrossRef]

124. Kuhn, T.S. The Structure of Scientific Revolutions, 1st ed.University of Chicago Press: Chicago, IL, USA, 1962.

(C) 2019 by the authors. Licensee MDPI, Basel, Switzerland. This article is an open access article distributed under the terms and conditions of the Creative Commons Attribution (CC BY) license (http:/ / creativecommons.org/licenses/by/4.0/). 